\title{
The Occurrence and Diversity of Flies Related to the Bali Cattle Breeding System in Badung Regency, Bali Province, Indonesia
}

\author{
I Made Dwinata ${ }^{1}$ and Ida Bagus Made $\mathrm{Oka}^{2}$ \\ 1,2 Department of Parasitology, Faculty of Veterinary Medicine, Udayana University, Denpasar, Bali, Indonesia \\ *Corresponding author: made_dwinata@unud.ac.id; okaibm@unud.ac.id
}

Article History: 21-325/339 Received: 04-Jun-21 Revised: 27-Jun-21 Accepted: 29-Jun-21
ABSTRA C T
This study aimed to determine the occurrence and diversity of flies' species in an intensive and extensive farming
system. The flies were collected from October to December 2019 by sweeping net in two cowsheds (intensive and
extensive farming system) on a private Bali cattle farm in Badung regency, Bali province, Indonesia. A total of 4125
flies belonging to 4 species (Stomoxys calcitrans, Musca domestica, Haematobia irritans, and Hippobosca sp.) were
obtained. At the intensive breeding system, the most collected flies were Stomoxys calcitrans (42.58\%) and the rare
ones were Hyppobosca sp. (3.25\%). At the extensive breeding system, the most collected flies were Stomoxys calcitrans
(33.86\%) and Haematobia irritans were the least abundant (11.36\%). Stomoxys calcitrans were observed abundance in
Mengwi district, whereas Musca domestica were highest in South Kuta district. It was concluded that the abundance of
flies during the study period was affected by farming system, temperature, humidity, and rainfall.

Key words: Diversity, Extensive farm, Flies, Intensive farm, Bali cattle

\section{INTRODUCTION}

Insects are unique in their way and contribute all types of services to the ecosystem. Their diversity is indeed an intrinsic part of the earth's ecosystem (Adelusi et al. 2018). Insects are important because of their diversity, ecological role, and influence on agriculture, human health, and natural resources (Premalatha et al. 2011; Halsch et al. 2020). They are one of the most diverse organisms (Skevington and Dang 2002) and are reported to be home to more than $58 \%$ of the global biodiversity on earth (Emmanuel and Anuoluwa 2019).

Over the last decade, insects have been managed to take a significant position in the feed and food chain. Insects can be used to feed fish, swine, poultry, and pets, (van Huis et al. 2020), also might help to reduce environmental pollution and increase animal welfare (Menozzi et al. 2021). However, they might carry biological and chemical contaminants as well as physical hazards that can be detrimental to the health. Insect also act as mechanical vectors of several bacterial, viral and protozoal diseases of livestock (Patra et al. 2018).

Insects, particularly flies, are also vectors of many pathogens. Flies can cause a decrease in livestock production and act as important vectors of infectious diseases, both directly and indirectly (Lucas et al. 2020);
Perez de Leon et al. 2020). Flies contribute to the spread of many pathogenic microorganisms and parasites. The direct impact of dipterans on livestock includes causing anxiety and stress in the animals, which results in reduced feeding, as well as skin lesions, facultative and accidental myiasis (Nosal et al. 2019), and potentially could disturb the health of many livestock. Flies also result in a significant economic loss to animal production because animals can get sick and spend a lot of energy avoiding the nuisance of fly bites (Taylor et al. 2012; Narladkar 2018).

Environmental conditions with favorable temperatures and poor enclosure sanitation conditions can be a very potent factor for an increase in the fly population (CollinetAdler et al. 2015). In general, flies show an increase in population during the rainy season and a decrease in the dry season. The reproduction of flies depends on temperature. The optimal temperature for rapid reproduction appears between an average temperature of $22.8-24^{\circ} \mathrm{C}$.

Climatic factors may however vary from one habitat to another, and this may affect the population trends of insects differently not only during some parts of the year but also different in different agroecological zones. This underscores the critical necessity of this work to evaluate the effect of climatic factors such as temperature, humidity, and rainfall on the population trends of insects associated with citrus orchards in two different agro-ecological zones in Ghana.

Cite This Article as: Dwinata IM and Oka IBM, 2022. The occurrence and diversity of flies related to the Bali cattle breeding system in Badung Regency, Bali Province, Indonesia. International Journal of Veterinary Science 11(1): 43-48. https://doi.org/10.47278/journal.ijvs/2021.075 
Raising cattle is associated with the accumulation of large amounts of manure. Manure plays an important role in the development and spreading of insects (Nosal et al. 2019). Each member of an insect responds differently to environmental changes. These different responses allow us to understand the important role of livestock grazing systems on biodiversity (Clement et al. 2018).

The Bali cattle rearing system is categorized in three ways, namely the extensive, semi-intensive, and intensive system (Sari et al. 2016). In an extensive breeding system, the cattle are released in the grazing field, allowed to feed. In the intensive breeding system, farmers kept their cattle in a paddock. Farmers bring and provide water and chopped or cut grass to their cattle in a pen. Intensive cattle farming, along with its dense population, is a rich source of manure, and increasing available manure. This situation provides an attractive environment for synanthropic insects and can increase flies diversity by adding new niches. Commonly, it is believed that the cattle production environment predominantly attracts by blood-sucking flies from the Muscidae family (Soviana et al. 2019). The occurrence and diversity of flies related to ruminant farming were reported the largest abundance of Diptera from the Drosophilidae family and dominating Muscidae species (Nosal et al. 2019).

The study is designed to document the diversity and infestation prevalence of flies in Badung, Bali Indonesia. In this study, the emphasis is on evaluating the breeding system, as well as the effect of temperature, humidity, and rainfall. This information is useful for agricultural, medical and veterinary purposes.

\section{MATERIALS AND METHODS}

\section{Study Area}

This research was conducted from October to December 2019 in the District of South Kuta and the district of Mengwi, Badung Regency of Bali Province. District of South Kuta covers $101.13 \mathrm{~km}^{2}$, a harsh, scrubby limestone plateau off the south side of Bali, which lies between latitude $-8.785502^{\circ}$ and longitude $115.199806^{\circ}$. The District of South Kuta is only $108 \mathrm{~m} / 354.33$ feet above sea level. The relative humidity is $82 \%$, from October to December the temperature is $26.3-26.9^{\circ} \mathrm{C}$. The rainfall throughout the year is $68-260 \mathrm{~mm}$. District of Mengwi covers an area of $82.0 \mathrm{~km}^{2}$, which lies between latitude $8.543465^{\circ}$ and longitude $115.171579^{\circ}$. The District of Mengwi is only $125 \mathrm{~m} / 410$ feet feet above sea level. The relative humidity is $76 \%$, from October to December the temperature is $28^{\circ} \mathrm{C}$. The rainfall throughout the year is 0.8 $\mathrm{mm}$.

\section{Sample Collection}

The flies were caught in a total of 107 private Bali cattle farms during a planned survey using a sweeping net. All flies were collected from an intensive (Fig. 1) and extensive farming system (Fig. 2). In the intensive breeding system, cattle are stall-fed year-round in the paddock. The farmers bring and provide water and feed in a paddock. In extensive farming, cattle move around freely in cowherd land, do not need extra feed. Caught flies were enumerated and all flies collected were preserved in $70 \%$ alcohol. The specimens were brought to the Parasitology Laboratory,
Faculty of Veterinary Medicine, Udayana University and identified using morphological differences described by Alikhan et al. (2016) and Phasuk et al. (2013).

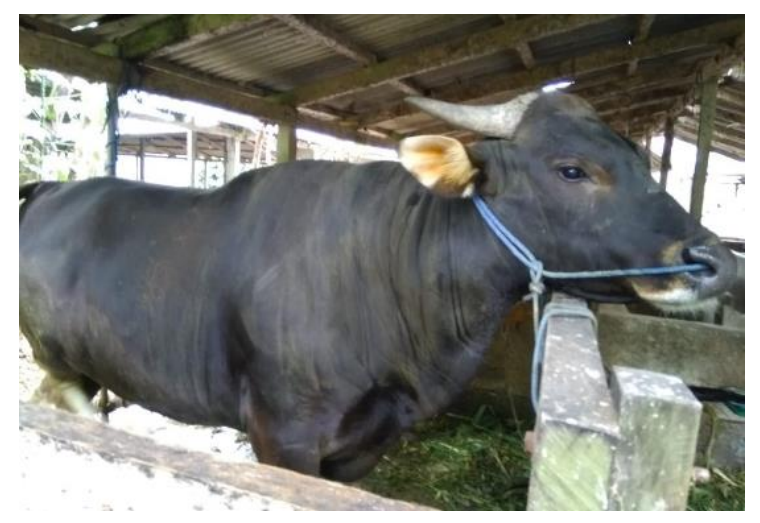

Fig. 1: Intensive breeding system.

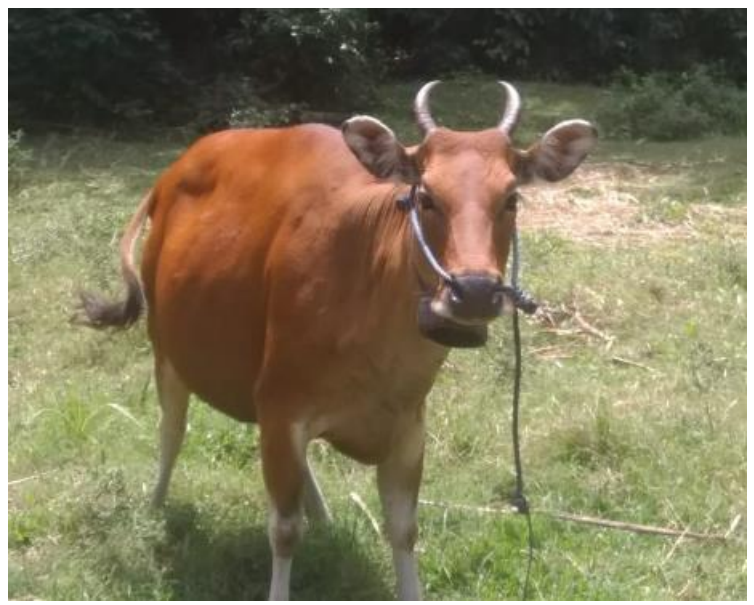

Fig. 2: Extensive breeding system.

\section{Data Analysis}

Data were analyzed using SPSS software (version 21) to determine the relationship between the farming system, temperature, humidity, and rainfall factors, and flies' abundance during these months (Szyniszewska et al. 2016). The differences between the number of flies and the farming system and the area were analyzed using the Student T-test $(\mathrm{P}<0.01)$.

\section{RESULTS}

A total of 4125 flies from 107 farms were sampled and only 105 flies could not be identified due to the damage of sample. A total of 2832 flies were collected in 147 cattle from the intensive farming system and 1188 flies in 153 cattle from the extensive farming system. A total of 4 species (Stomoxys calcitrans (Fig. 3), Musca domestica (Fig. 4), Haematobia irritans (Fig. 5), and Hippobosca sp. (Fig. 6) were identified in this research (Table 1). At the intensive farming system, the most collected flies were Stomoxys calcitrans $(42.58 \%)$ and the rare ones were Hyppobosca sp. (3.25\%). The highest prevalence of the flies species in the intensive farming system were Stomoxys calcitrans with the prevalence of $42.58 \%$, followed by Musca domestica (40.61\%), Haematobia irritans (13.56\%), and Hyppobosca sp. (3.25\%). However, in an 
Int J Vet Sci, 2022, 11(1): 43-48.
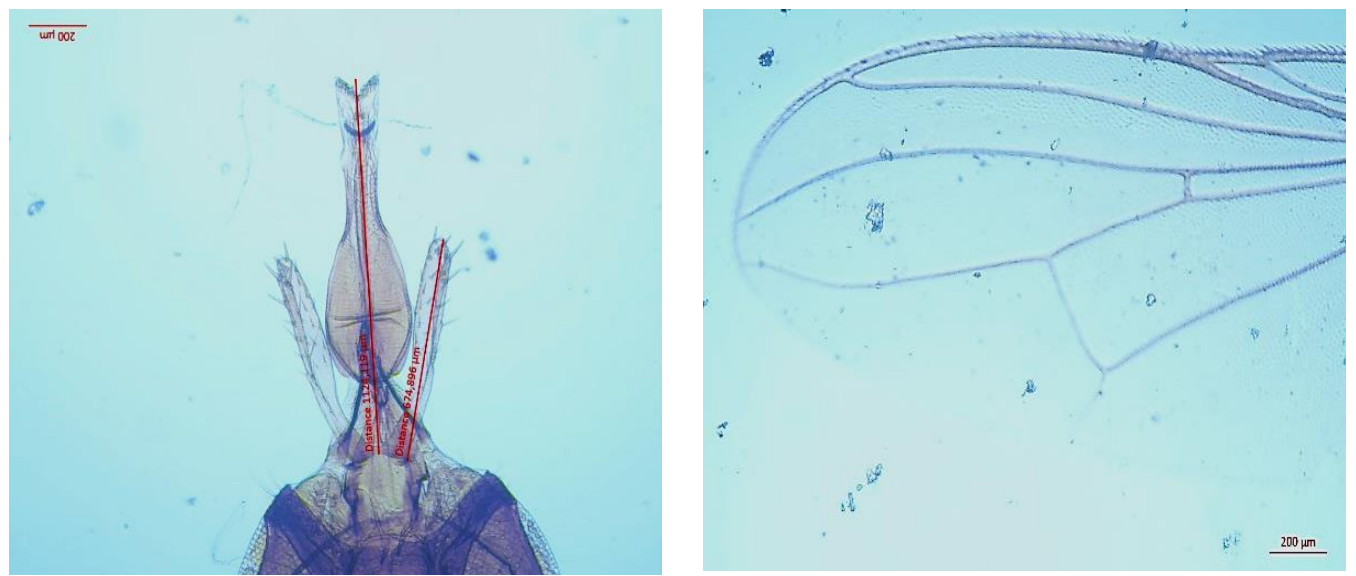

Fig. 3: Stomoxys calcitrans (left: head, right: wing vein),
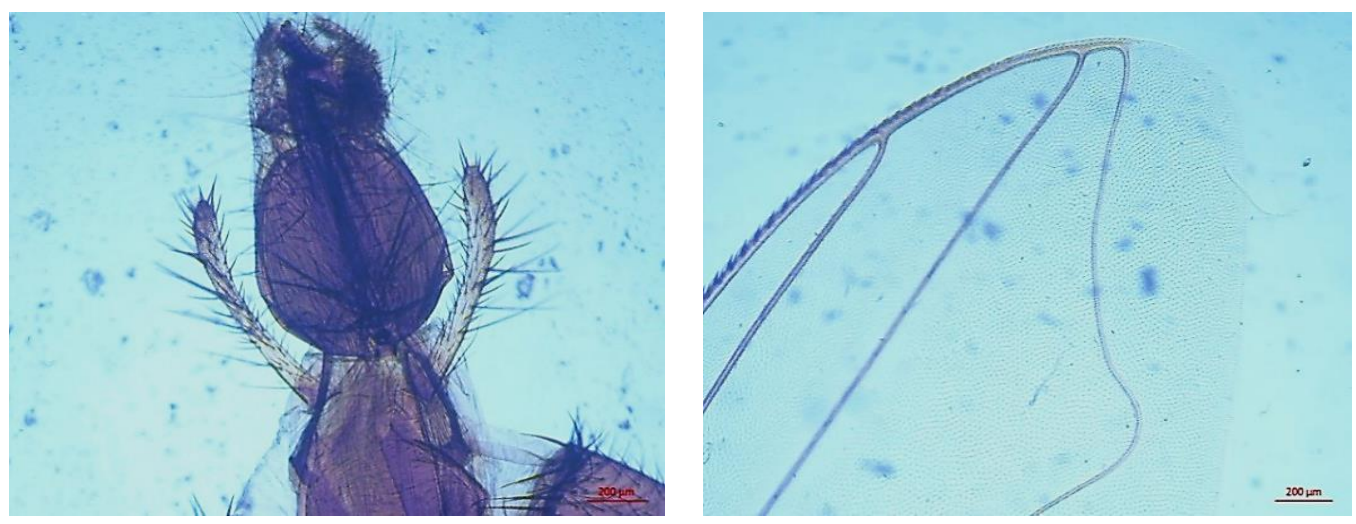

Fig. 4: $M u s c a$ domestica (left: head; right: wing vein).

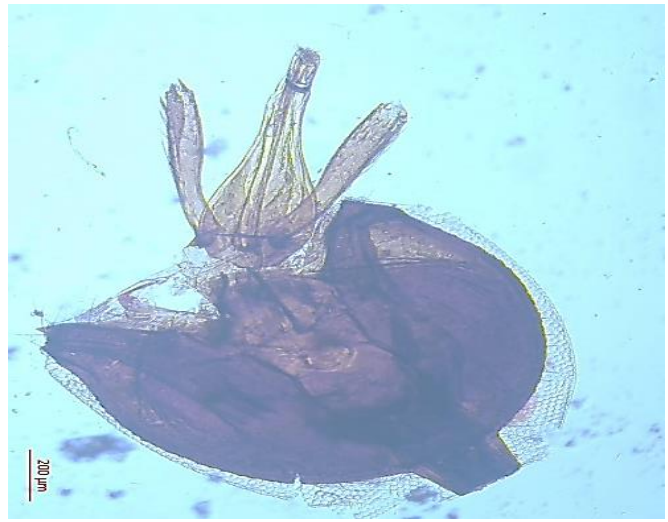

Fig. 5:

Haematobia sp. (left: head, right: wing vein).
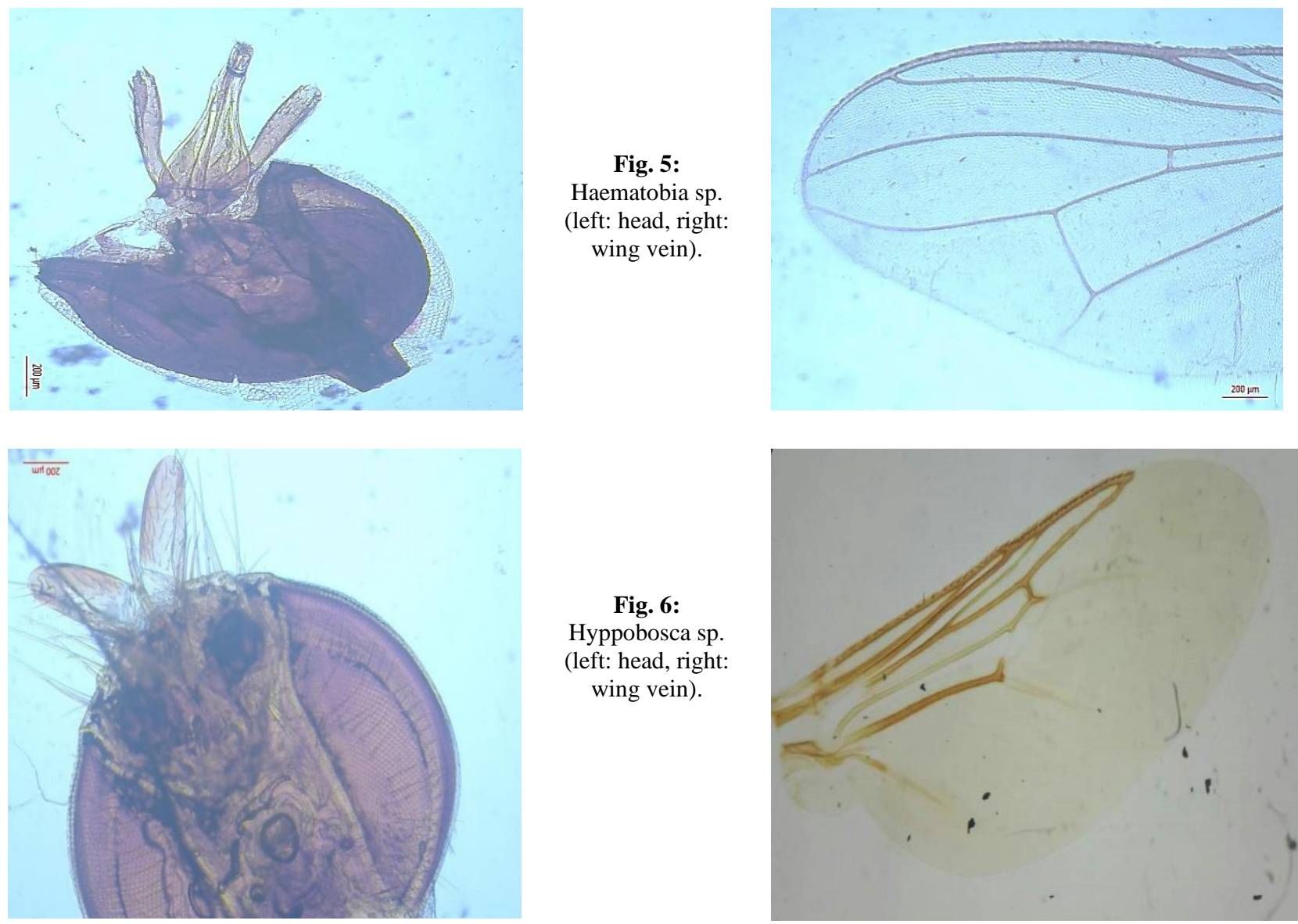

extensive farming system, Haematobia irritans were the least abundant (11.36\%) (Table 1). Average overall flies abundance was significantly greater $(\mathrm{P}<0.05)$ at intensive farming system with extensive farming. The infestation of

Hyppobosca sp. in the extensive farming system (25.42\%) was higher when compared to the intensive farming system $(3.25 \%)$. 
Table 1: Total number and proportion (\%) of individual flies' species captured in the survey at the intensive and extensive farming system

\begin{tabular}{llll}
\hline No & Species & $\begin{array}{l}\text { Intensive } \\
\text { farming system }\end{array}$ & $\begin{array}{l}\text { Extensive } \\
\text { farming system }\end{array}$ \\
\hline 1 & Stomoxys calcitrans & $1206(42.58)$ & $426(35.86)$ \\
2 & Musca domestica & $1150(40.61)$ & $325(27.36)$ \\
3 & Haematobia irritans & $384(13.56)$ & $135(11.36)$ \\
4 & Hyppobosca sp. & $92(3.25)$ & $302(25.42)$ \\
\hline
\end{tabular}

Values in parenthesis indicate percentage.

Based on the area, species diversity is presented in Table 2. The result on four species was collected, frequency of occurrence for distribution of Stomoxys sp. was higher in the district of Mengwi than in South Kuta district. In contrast, Musca sp. were significantly higher collected in South Kuta district. Focusing on four species, Musca sp. was observed to increase with increasing humidity and rainfall, whereas Stomoxys sp. was found to be increased with decreasing rainfall and humidity.

Table 2: Total number of flies collected in at South Kuta and Mengwi District

\begin{tabular}{lll}
\hline Species of flies & \multicolumn{2}{c}{ Regions } \\
\cline { 2 - 3 } & $\begin{array}{l}\text { South Kuta } \\
(\mathrm{n}=2108)\end{array}$ & $\begin{array}{l}\text { Mengwi } \\
(\mathrm{n}=1912)\end{array}$ \\
\hline Stomoxys calcitrans & $669(31.74)$ & $963(50.4)$ \\
Musca domestica & $1018(48.29)$ & $457(23.90)$ \\
Haematobia irritans & $244(11.57)$ & $275(14.35)$ \\
\hline Hippobosca sp. & $177(8.40)$ & $217(11.35)$ \\
\hline
\end{tabular}

Values in parenthesis indicate percentage.

\section{DISCUSSION}

The flies collected in this study differed in numbers between the farms examined, however, the farming system has the same distribution in species composition of insects. The fly species abundance and diversity were observed, and the differences were significant between the intensive and extensive farming system. It is an indication that the sites of the farm occupy a different management system. The diversity of flies in cattle depends on differences in region, season, and management breeding system. The overall most abundant insect in the intensive farming system was Stomoxys calcitrans followed by Musca domestica, Haematobia irritants, and Hyppobosca sp. were rarely found in the intensive farming system.

This research shows most abundant flies were the Stomoxys calcitrans and it occurred abundantly in an intensive and extensive farming system than the other detected flies. The abundant population of Stomoxys calcitrans is probably because this location is good habitat as well as the suitable environmental conditions for Stomoxys calcitrans larvae that complete their life cycle. Rainfall fluctuations may be the main climatic factor correlated with population changes of the most abundant species (Phasuk et al. 2013). Stomoxys calcitrans is, is a cosmopolitan haematophagous fly that frequently attacks livestock in farmyards (Murchie et al. 2018) and considered a major pest of livestock worldwide (Shukri Sharif et al. 2020). Stomoxys calcitrans is a species considered to be one of the most harmful in livestock breeding and raising around the world (Nosal et al. 2019). The research in Minahasa, Indonesia reported that Stomoxys calcitrans was a relatively high population than other flies such as
Stomoxys sp., Haematobia sp. and Musca sp. (Djenaan et al. 2019).

Besides Stomoxys sp. during this research, Musca sp. was the most common flies on this farm. Musca sp. tends to be most abundant than Hippobosca sp. and Haematobia sp. This study showed the two farming systems had an equal number of Musca sp. In another study, Djenaan et al. (2019) showed that Haematobia sp. was the most common flies on the cattle farm. This may be because of the difference in location. Musca sp. can breed in cattle dung, and the adult stage feeds on secretions from cattle (Soviana et al. 2019). Some species of Musca flies can be a biological vector of Thelazia eyeworm disease that occurs when flies feed on cattle's tear secretions (Canie and Bogale 2014). Habits of Musca sp. which easily alighted then flew around the body of livestock, can become one of the potential disease vectors.

Our study also revealed that the Hippobosca sp. are rare species in the extensive farming system compared to the extensive farming system. The relatively high population of Hippobosca sp. at the extensive farming system is likely due to the environmental conditions suitable for Hippobosca sp. larvae completing their life cycle. In the extensive farming system, cattle move around freely on cowherd land. The cows will pass their feces in a variety of different places, and this will prevent the accumulation of feces in one place. The manure spill around the farm is excellent for scrub and tree growth. Scrub and trees around the farm are a good location for Hippobosca sp. put their pupae (Soviana et al. 2019).

In this study, infestation of Haematobia sp. in extensive farming system was the lowest when compared to others flies. These species were present at $11.3 \%$ Haematobia sp. is a bloodsucking fly in the form of the same palpus and proboscis, and the palpus was a sturdy type (Soviana et al. 2019). A different prevalence was observed in California. Haematobia sp. was the most common fly observed in cattle breeding areas in Californiais an obligate parasite that is always present on a cattle's body and can potentially be a mechanical vector for surra caused by Trypanosoma evansi (Desquesnes et al. 2013).

Climate changes have significant impacts directly on insects. Direct impacts are on insect reproduction, development, survival and dispersal. Insects are poikilothermic organisms; the temperature of their body depends on the temperature of the environment. Thus, the temperature maybe the most important factor affecting insect distribution, development, and reproduction. Since temperature is the most important environmental factor affecting insect population dynamics (Skendži'c et al. 2021).

Stomoxys sp. were considered a major pest of livestock in Badung Bali. The abundance of these flies is observed in the Mengwi district and low in the South Kuta district. The differences could be due to temperature, humidity, and rainfall in the two district areas. The temperature was reported to affect the population peak of Stomoxys sp. (Semelbauer et al. 2018). Humidity was observed to have a significant effect in increasing the number of larva pupated (Issimov et al. 2020). Rainfall has also been reported to affect Stomoxys activity. The increase in rainfall causes a critical factor for eggs to hatch and the 
larvae to survive and successfully develop into pupae (Lendzele et al. 2019). The low number of flies trapped in the South Kuta district may be caused by increase rainfall in these months.

Musca domestica (known as the common housefly) numbers were highest during this study in South Kuta district compared in Mengwi district. In the South Kuta district, the relative humidity and rainfall were highest compared to the Mengwi district. The differences in Musca domestica population could be due to differences in temperature, humidity and rainfall. The temperature and relative humidity affect the Musca domestica development and prevalence (Jiméneza et al. 2019). Musca domestica have favourable production performances at higher temperature (Francuski et al. 2020). It was evident that the abundance of flies during the study period was affected by farming system, temperature, humidity and rainfall in Badung regency.

\section{Conclusion}

Among captured samples, the most abundant species were Stomoxys sp. and the rare species were Hyppobosca sp. in intensive farming systems, and Haematobia irritans in the extensive farming system. Stomoxys calcitrans were observed abundant in Mengwi district, whereas Musca domestica were highest in South Kuta district. This information could deepen the knowledge of the ecology of flies in Bali cattle. Further research is needed to expand using other sampling techniques and seasonal variation effect on flies' abundance in Bali.

\section{Acknowledgment}

This research was financed by The DIPA BLU, Udayana University, Bali Indonesia under the Work Agreement (SPK) Number: 1231/UN14.2.9/LT/.

\section{Authors Contribution}

All the authors contributed significantly to the paper.

\section{REFERENCES}

Adelusi SM, Ada RT and Omudu EA, 2018. Diversity and abundance of insects species in Makurdi, Benue State, Nigeria. International Journal of New Technology and Research 4: 52-57.

Alikhan M, Al Ghamdi K, Mahyoub JA and Alanazi N, 2016. Public health and veterinary important flies (Order: Diptera) prevalent in Jeddah Saudi Arabia with their dominant characteristics and identification key. Saudi Journal of Biological Sciences 25: 1648-1663. http://dx.doi.org/ 10.1016/j.sjbs.2016.08.014

Canie $\mathrm{M}$ and Bogale B, 2014. Thelaziasis: biology, species affected and patholog (conjunctivitis): A review. Acta Parasitologica Globalis 5: 65-68. https://doi.org/10.5829/ idosi.apg.2014.5.1.8345

Clement RA, Frandsen PB, McKnight T and Nelson CR, 2018. Fly family diversity shows evidence of livestock grazing pressure in Mongolia (Insecta: Diptera). Journal of Insect Conservation 22: 231-243. https://doi.org/10.1007/s10841018-0056-x

Collinet-Adler S, Babji S, Francis M, Kattula D, Premkumar PS, Sarkar R, Mohan VR, Ward H, Kang G, Balraj V and Naumova EN, 2015. Environmental factors associated with high fly densities and diarrhea in Vellore, India. Applied and
Environmental Microbiology 81: 6053-6058. http://dx.doi.org/10.1128/AEM.01236-15

Desquesnes M, Dargantes A, Lai DH, Lun ZR, Hulzmuller P and Jittapalapong S, 2013. Trypanosoma evansi and surra: A review and perspective on transmission, epidemiology and control, impact, and zoonotic aspect. BioMed Research International 1-20. https://doi.org/10.1155/2013/194176

Djenaan F, Assa GJV, Poli Z and Lomboan A, 2019. Jenis dan populasi lalat pada ternak sapi di desa Tolok, Kecamatan Tompaso, Kabupaten Minahasa. Zootec 39: 51-56. https://doi.org/10.35792/zot.39.1.2019.22130

Emmanuel O and Anuoluwa YO, 2019. A study on the diversity and relative abundance of insect fauna in Wukari, Taraba State, Nigeria. International Journal of Advanced Biological and Biomedical Research 7: 129-141. https://doi.org/ 10.33945/SAMI/IJABBR.2019.2.4

Francuski L, Jansen W and Beukeboom LW, 2020. Effect of temperature on egg production in the common housefly. Entomologia Experimentalis et Applicata 168: 513-522. https://doi.org/10.1111/eea.12912

Halsch CA, Shapiro AM, Fordyce JA, Nice CC, Thorne JH, Waetjen DP and Foristera ML,2021. Insects and recent climate change. Proceedings of the National Academy of Sciences of the United States of America 118: e2002543117 https://doi.org/10.1073/pnas.2002543117

Issimov A, Taylor DB, Zhugunissov K, Kutumbetov L, Zhanabayev A, Kazhgaliyev N, Akhmetaliyeva A, Nurgaliyev B, Shalmenov M, Absatirov G, Dushayeva L and White PJ, 2020. The combined effects of temperature and relative humidity parameters on the reproduction of Stomoxys species in a laboratory setting. PLoS One 15: e0242794. https://doi.org/10.1371/ journal.pone.0242794

Jiméneza AJM, Santos AL, Munguía CAG, González JAT and Munguía AMG, 2019. Potential distribution of Musca domestica in Jesús María Municipality, Aguascalientes, Mexico, based on climate change scenarios. Revista Mexicana de Ciencias Pecuarias 10: 14-29. http://dx.doi.org/ 10.22319/rmcp.v10i1.4241

Lendzele SS, François MJ, Roland ZKC, Armel KA and Duvallet G, 2019. factors influencing seasonal and daily dynamics of the genus Stomoxys Geoffroy, 1762 (Diptera: Muscidae), in the Adamawa Plateau, Cameroon. International Journal of Zoology 2019: Article \# 3636943. https://doi.org/10.1155/ 2019/3636943

Lucas M, Krolow TK, Riet-Correa F, Barros ATM, Krüger RF, Saravia A and Miraballes C, 2020. Diversity and seasonality of horse flies (Diptera: Tabanidae) in Uruguay. Scientific Reports 10: 401. https://doi.org/10.1038/s41598-019-57356$\underline{0}$

Menozzi D, Sogari G, Mora C, Gariglio M, Gasco L and Schiavon A, 2021. Insects as feed for farmed poultry: Are Italian consumers ready to embrace this innovation? Insects 12 : 435. https://doi.org/10.3390/insects12050435

Murchie AK, Hall CE, Gordon AW and Clawson S, 2018. Black border increases Stomoxys calcitrans catch on white sticky traps. Insects 9: 13. https://doi.org/10.3390/insects9010013

Narladkar BW, 2018. Projected economic losses due to vector and vector-borne parasitic diseases in livestock of India and its significance in implementing the concept of integrated practices for vector management. Veterinary World 11: 151160. https://dx.doi.org/10.14202\%2Fvetworld.2018.151-160

Nosal P, Kowal J, Węglarz A and Wyrobisz-Papiewsk A, 2019. The occurrence and diversity of flies (Diptera) related to ruminant farming in southern Poland. Annals of Parasitology 65: 357-363. https://doi.org/10.17420/ap6504.221

Patra G, Behera P, Das SK, Saikia B, Ghosh S, Biswas P, Kumar A, Alam SS, Kawlni L, Lalnunpuia C, Lalchhandama C, Bachan M and Debbarma A, 2018. Stomoxys calcitrans and its importance in livestock: a review. International Journal of 
Int J Vet Sci, 2022, 11(1): 43-48.

Advance Agricultural Research 6: 30-37. https://doi.org/ 10.33500/ijaar.2018.06.003

Perez de Leon AA, Mitchell RD and Watson DW, 2020. Ectoparasite of cattle. Veterinary Clinics of North America: Food Animal Practice 36: 173-185. https://doi.org/ 10.1016/j.cvfa.2019.12.004

Phasuk J, Prabaripai A and Chareonviriyaphap T, 2013. Seasonality and daily flight activity of stable flies (Diptera: Muscidae) on dairy farms in Saraburi Province, Thailand. Parasite 20: 1-7. http://dx.doi.org/10.1051/parasite/2013016

Premalatha M, Abbasi T, Abbasi T and Abbasi SA, 2011. Energyefficient food production to reduce global warming and ecodegradation: The use of edible insects. Renewable and Sustainable Energy Reviews 15: 4357-4360. http://dx.doi.org/10.1016/j.rser.2011.07.115

Sari DDK, Busono W and Nugroho H, 2016. Cattle production performance in semi-intensive and extensive farming system from Jembrana District, Bali, Indonesia. Research in Zoology 6: 17-20. https://doi.org/10.5923/j.zoology. 20160602.01

Semelbauer M, Mangová B, Barta M and Kozánek M, 2018. The factors influencing seasonal dynamics and spatial distribution of stable fly Stomoxys calcitrans (Diptera, Muscidae) within Stables. Insects 9: 142. http://dx. doi:10.3390/insects 9040142

Shukri Sharif S, Liénard E, Duvallet G, Etienne L, Mongellaz C, Grisez C, Franc M, Bouhsira E and Jacquiet P, 2020.
Attractiveness and specificity of different polyethylene blue screens on Stomoxys calcitrans (Diptera: Muscidae). Insects 11: 575. http://dx.doi.org/10.3390/insects11090575.

Skendži'c S, Zovko M, Paja c I, Živkovi'c, Leši'c V and Lemi'c D, 2021. the impact of climate change on agricultural insect pests. Insects 12: 440. https://doi.org/10.3390/insects 12050440

Skevington JH and Dang PT, 2002. Exploring the diversity of flies (Diptera). Biodiversity 2: 1-44. https://doi.org/ 10.1080/14888386.2002.9712613

Soviana S, Hadi UK and Putra AK, 2019. Diversity and activity of bloodsucking flies (Diptera: Muscidae) in Cibungbulang dairy farm, Bogor regency Indonesia. Journal of Entomology and Zoology Studies 7: 738-774.

Szyniszewska AM, Leppla NC, Huang Z and Tatem AJ, 2016. Analysis of seasonal risk for importation of the mediterranean fruit fly, Ceratitis capitata (Diptera: Tephritidae), via air passenger traffic arriving in Florida and California. Journal of Economic Entomology 109: 2317 2328. https://doi.org/10.1093/jee/tow196

Taylor DB, Moon RD and Mark DR, 2012. Economic impact of stable flies (Diptera: Muscidae) on dairy and beef cattle production. Journal of Medical Entomology 49: 198-209. http://dx.doi.org/10.1603/ME10050

van Huis A, Oonincx DGAB, Rojo S and Tomberlin JK, 2020. Insects as feed: house fly or black soldier fly? Journal of Insects as Food and Feed 6: 221-229. http://dx.doi.org/ 10.3920/JIFF2020.x003 